\title{
Upaya Meningkatkan Kemampuan Mengurutkan Bilangan Dengan Menggunakan Alat Peraga Kartu Bilangan Siswa Kelas 1 Sd Negeri 4 Kabupaten Sorong Tahun Pelajaran 2015/2016
}

\author{
Satnauli Sirait \\ SD Negeri 4 Kabupaten Sorong \\ Email: satnaulisirait_sdn4@gmail.com
}

\begin{abstract}
This research is a classroom action research which has purpose for improving the students' ability to make a number in sequence by using visual aid of numbering card on Mathematics of I grade students at SD Negeri 4 Sorong Regency for academic year 2015/2016. This research was conducted in two cycles which every cycle consisted of planning, action, observation and reflection. The subject of this research was the $I^{\text {st }}$ grade students of SD Negeri 4 Sorong Regency which consisted of 22 students. The techniques of collecting data used were observation and test. The data was analyzed by using descriptive qualitative analysis. Based on the result, the learning process in mathematics on the $1^{\text {st }}$ cycle shown that the students' understanding classically was still under the standard of Minimum Completeness Criteria (KKM) that was 60, with the average of class who passed the KKM was 68\% or 15 students from 22 students. Meanwhile, on the $2^{\text {nd }}$ cycle shown an improvement on students' understanding on Mathematics, with the average of the class was $85 \%$ or 19 students and there was an improvement on class average was $86,36 \%$.
\end{abstract}

Keywords: number sequence, Mathematics, visual aid, students' ability, SD Negeri 4 Sorong Regency

\begin{abstract}
Abstrak: Penelitian ini adalah Penelitian Tindakan Kelas yang bertujuan untuk meningkatkan kemampuan mengurutkan bilangan dengan menggunakan alat peraga kartu bilangan pada pembelajaran Matematika kelas 1 siswa SD Negeri 4 Kabupaten Sorong tahun pelajaran 2015/ 2016. Penelitian ini dilakukan dalam dua siklus dan masing-masing siklus terdiri dari perencanaan, tindakan, observasi dan refleksi. Subjek penelitian ini adalah siswa kelas 1 SD Negeri 4 Kabupaten Sorong dengan jumlah siswa sebanyak 22 siswa. Teknik pengumpulan data yang digunakan dalam penelitian ini adalah tes dan observasi. Data dianalisis dengan menggunakan analisis deskriptif kuantitatif. Berdasarkan hasil analisis data pada proses pembelajaran pada siklus I, bahwa proses pembelajaran Matematika memperlihatkan bahwa tingkat pemahaman siswa secara klasikal masih dibawah standar KKM kelas 60 dan nilai rata-rata kelas adalah 68\% atau hanya 15 anak yang tuntas dari 22 anak. Hasil evaluasi siklus II menunjukkan perubahan peningkatan pemahaman siswa pada materi Matematika yakni sebesar $85 \%$ atau sebanyak 19 siswa yang tuntas belajarnya dan terjadi peningkatan rata-rata kelas sebesar $86,36 \%$.
\end{abstract}


Kata kunci: urutan bilangan, Matematika, alat peraga, kemampuan siswa, SD Negeri 4 Kabupaten Sorong

\section{Pendahuluan}

Pembelajaran Matematika di SD merupakan salah satu kajian yang menarik untuk dikemukakan karena adanya perbedaan karakteristik khususnya antara hakekat anak dan hakekat matematika. Oleh karena itu, diperlukan adanya jembatan yang dapat menetralisir perbedaan tersebut. Anak usia SD sedang mengalami perkembangan pada tingkat berfikirnya. Hal ini dikarenakan tahap berfikir mereka masih belum formal, bahkan tidak jarang para siswa SD di kelas rendah cara berfikirnya masih berada pada tahapan pra-konkrit.

Banyak orang yang tidak menyukai matematika termasuk anak-anak yang masih duduk di bangku sekolah dasar. Mereka menganggap bahwa matematika sulit dipelajari serta gurunya kebanyakan tidak menyenangkan, membosankan dan menakutkan. Anggapan ini menyebabkan mereka semakin takut belajar matematika. Sikap ini tentu saja mengakibatkan prestasi belajar matematika menjadi rendah, akibat lebih lanjut mereka menjadi semakin tidak suka terhadap matematika. Karena takut dan tidak suka belajar matematika, maka prestasi belajar mereka menjadi semakin menurun. Hal ini perlu mendapat perhatian khusus dari para guru khususnya guru sekolah dasar untuk melakukan suatu upaya dalam meningkatkan minat dan prestasi belajar Matematika peserta didiknya.

Hal ini juga dialami oleh siswa kela 1 SD Negeri 4 Kabupaten Sorong. Prestasi belajar mereka menurun terutama pada pelajaran Matematika tentang mengurutkan bilangan. Diketahui hanya 11 dari 22 siswa atau 50\% mendapat nilai yang memenuhi standar KKM sedangkan sisanya belum mencapai standar KKM yang telah ditetapkan yaitu 60. Sementara itu, nilai rata-rata kelas yang diperoleh adalah 54 .

Ketidakberhasilan guru dalam pembelajaran Matematika disebabkan oleh: guru kurang menarik dalam menyampaikan materi pelajaran, guru kurang maksimal dalam menggunakan media dan alat peraga pembelajaran, guru kurang mengaktifkan siswa dalam pembelajaran, guru kurang membimbing dalam kegiatan diskusi kelompok, guru kurang bervariasi dalam penggunaan metode pembelajaran.

Berdasarkan permasalahan tersebut, penelitian ini bertujuan untuk meningkatkan hasil belajar siswa tentang mengurutkan bilangan pada siswa kelas 1 melalui penggunaan alat peraga kartu bilangan.

\section{Metode Penelitian}

\subsection{Desain Penelitian}


Penelitian ini merupakan penelitian tindakan kelas. Penelitian ini terdiri dari 2 siklus dimana masing-masing siklus terdiri dari perencanaan, tindakan, observasi dan refleksi. Berikut penjabaran dari masing-masing tahapan:

1) Perencanaan

Pada tahap ini, peneliti menyusun aktivitas-aktivitas pembelajaran matematika dengan menggunakan alat peraga.

2) Pelaksanaan

Pelaksanaan penelitian dilaksanakan sesuai dengan rencana perbaikan pembelajaran yang telah tersusun dalam dua siklus. Dalam tahap ini, peneliti dibantu oleh teman sejawat yang merangkap sebagai observer. Pelaksanaan penelitian secara umum berlangsung mulai dari kegiatan awal, kegiatan inti, kegiatan perbaikan, kegiatan akhir dan tindak lanjut. Sedangkan secara khusus, perbaikan pembelajaran dilakukan melalui aktivitas perbaikan pada kegiatan inti pada siklus I dan siklus II.

\section{3) Pengamatan}

Peneliti dibantu oleh teman sejawat untuk mengidentifikasi kelebihan dan kekurangan dalam perbaikan pembelajaran yang dilaksanakan. Oleh pengamat, kekurangan dan kelebihan itu dicatat dalam lembar observasi. Pada akhir pelaksanaan perbaikan pembelajaran, peneliti mengadakan tes perbaikan atau evaluasi.

\section{4) Refleksi}

Setelah melaksanakan tindakan dan pengamatan, peneliti mengadakan diskusi dengan teman sejawat dan supervisor untuk mengetahui kemampuan siswa dalam menyelesaikan soal-soal mengurutkan bilangan menggunakan alat peraga kartu bilangan.

\subsection{Subjek Penelitian}

Subjek penelitian ini adalah siswa kelas 1 SD Negeri 4 Kabupaten Sorong yang berjumlah 22 siswa. Siswa terdiri dari 10 laki-laki dan 12 perempuan.

\subsection{Lokasi dan Waktu Penelitian}

Penelitian ini dilaksanakan di SD Negeri 4 Kabupaten Sorong. Penelitian dilakukan pada bulan Oktober 2015.

\subsection{Teknik Pengumpulan Data}

Data dalam penelitian ini dikumpulkan dengan menggunakan beberapa teknik, yakni observasi, wawancara dan tes.

\subsection{Teknik Analisis Data}


Data yang sudah terkumpul akan dianalisis secara kuantitatif dan kualitatif, yaitu menggunakan:

1) Data kuantitatif berupa hasil belajar kognitif, dianalisis dengan menggunakan teknik analisis deskriptif dengan menentukan rerata atau mean. Adapun penyajian data kuantitatif dipaparkan dalam bentuk presentase dengan rumus:

$$
\mathrm{P}=\frac{\sum n}{\mathrm{~N}} \times 100 \%
$$

$$
\begin{aligned}
& \text { Keterangan: } \\
& \mathrm{P} \quad=\text { persentase frekuensi kemunculan } \\
& \sum n \quad=\text { jumlah frekuensi kemunculan } \\
& \mathrm{N} \quad=\text { jumlah total siswa }
\end{aligned}
$$

\begin{tabular}{|c|c|}
\hline Kriteria Ketuntasan & Kualifikasi \\
\hline$\geq 60$ & Tuntas \\
\hline$<60$ & Tidak Tuntas \\
\hline
\end{tabular}

Hasil penghitungan dikonsultasikan dengan criteria ketuntasan belajar siswa yang dikelompokkan ke dalam dua kategori tuntas dan tidak tuntas dengan criteria sebagai berikut:

2) Data kualitatif berupa data hasil observasi aktifitas siswa, aktifitas guru dalam pembelajaran mengurutkan bilangan serta hasil catatan lapangan dan wawancara dianalisis dengan deskriptif kualitatif.

\section{Hasil Penelitian dan Pembahasan}

\subsection{Hasil Penelitian}

Penelitian dilaksanakan dalam 2 siklus. Penyampaian hasil penelitian pada masing-masing siklus mencakup penilaian penampilan perbaikan pembelajaran dan hasil belajar. Sebelum dberikan tindakan diperoleh data analisis dari hasil ulangan siswa kelas I sebagai berikut:

Tabel 1. Perolehan Nilai Pra siklus

\begin{tabular}{lcc}
\hline No. & Nilai & Jumlah Siswa \\
\hline 1 & $91-100$ & - \\
2 & $81-90$ & 2
\end{tabular}




$$
\begin{gathered}
71-80 \\
61-70 \\
51-60 \\
41-50 \\
31-40 \\
21-30 \\
11-20 \\
0-10
\end{gathered}
$$

$$
\begin{aligned}
& 2 \\
& 2 \\
& 5 \\
& 3 \\
& 4 \\
& 4
\end{aligned}
$$

setelah diadakan ulangan harian awal, nilai yang diperoleh siswa tidak sesuai dengan harapan guru. Siswa yang mendapat nilai di atas 60 sebanyak 11 siswa atau $50 \%$.

Pada siklus I guru mencoba menjelaskan materi dengan lebih sistematis dengan menggunakan alat peraga berupa kartu bilangan. Selain itu, guru juga memberikan banyak latihan kepada siswa, baik latihan tertulis maupun latihan dengan menggunakan alat peraga yang dapat memudahkan siswa. Berikut adalah hasil analisis ulangan siswa setelah diberikan tindakan pada siklus I.

Tabel 2. Perolehan Nilai Siklus I

\begin{tabular}{lcc}
\hline No. & Nilai & Jumlah Siswa \\
\hline 1 & $91-100$ & 3 \\
2 & $81-90$ & 1 \\
3 & $71-80$ & 5 \\
4 & $61-70$ & 3 \\
5 & $51-60$ & 3 \\
6 & $41-50$ & 4 \\
7 & $31-40$ & 3 \\
8 & $21-30$ & - \\
9 & $11-20$ & - \\
10 & $0-10$ & - \\
\hline
\end{tabular}

Pada siklus I siswa yang mendapat nilai lebih dari 60 baru mencapai 15 siswa atau $68 \%$ yang disertai peningkatan keaktifan siswa dalam kegiatan pembelajaran sedangkan 7 siswa lainnya belum berhasil. Oleh karena itu, guru bersama teman sejawat mencoba mengevaluasi kekurangan yang masih menjadi penghambat dalam keberhasilan pembelajaran. Kekuangan yang ditemukan antara lain 
adalah pemberian tugas atau latihan soal bagi siswa karena untuk latihan yang diberikan pada siswa masih sangat kurang dan guru masih kurang dalam memberikan bimbingan dan memotivasi siswa untuk aktif dalam kegiatan belajar. Setelah guru menemukan kekurangannya, guru berusaha mengadakan perbaikan pembelajaran pada siklus II.

Pada siklus II model pembelajaran yang digunakan tetap sama dan guru lebih sistematis dalam merencanakan diskusi kelompok agar kegiatan diskusi dapat berjalan lebih baik. Setelah itu siswa diberikan kesempatan untuk berdiskusi dan menanyakan kesulitan yang dialaminya selama proses pembelajaran, sehingga guru dapat langsung melakukan pendekatan kepada masing-masing siswa. Selain itu, guru juga melakukan perbaikan alat peraga agar dalam menjelaskan materi siswa lebih mudah dipahami. Dengan penggunaan alat peraga dan pemberian latihan soal yang cukup bagi siswa terbukti siswa lebih aktif dalam kegiatan pembelajaran dan hasil yang diperoleh siswa cukup memuaskan.

Berikut adalah hasil analisis ulangan siswa setelah diberikan tindakan pada siklus II

Tabel 3. Perolehan Nilai Siklus II

\begin{tabular}{lcc}
\hline No. & Nilai & Jumlah Siswa \\
\hline 1 & $91-100$ & 10 \\
2 & $81-90$ & 3 \\
3 & $71-80$ & 4 \\
4 & $61-70$ & 1 \\
5 & $51-60$ & 1 \\
6 & $41-50$ & 3 \\
7 & $31-40$ & - \\
8 & $21-30$ & - \\
9 & $11-20$ & - \\
10 & $0-10$ & - \\
\hline
\end{tabular}

Rata-rata kelas 85

Pada siklus II, terjadi peningkatan prestasi belajar siswa yang signifikan. Dari 22 siswa, 19 siswa atau $85 \%$ siswa sudah mendapat nilai di atas 60 sedangkan jumlah siswa yang belum berhasil hanya 3 siswa. Hal ini membuktikan bahwa penggunaan alat peraga dan metode yang tepat dalam pembelajaran dapat meningkatkan motivasi dan hasil belajar siswa dan pemanfaatan alat peraga secara maksimal sangat menunjang keberhasilan dalam pembelajaran. 
Perbaikan pembelajaran Matematika juga meningkatkan prosentase ketuntasan belajar siswa. Perhitungan prosentase ketuntasan belajar siswa ini dicantumkan pada tabel berikut:

Tabel 4. Prosentase Ketuntasan Belajar Matematika

\begin{tabular}{ccccc}
\hline No. & Pelaksanaan & Jumlah siswa tuntas & Prosentase & Keterangan \\
\hline 1 & Prasiklus & 11 & $50 \%$ & Minimal \\
2 & Siklus I & 15 & $68 \%$ & Meningkat \\
3 & Siklus II & 19 & $85 \%$ & Maksimal \\
\hline
\end{tabular}

\subsection{Pembahasan}

Pada tahap pra siklus suasana proses kegiatan belajar mengajar terlihat masih kurang aktif dan interaksi guru dengan siswa cenderung masih satu arah. Perolehan nilai dari hasil tes formatif sangat rendah. Dari 22 siswa, tingkat ketuntasan baru mencapai 50\% dari target 70\%-100\%. Setelah diadakan tindakan pembelajaran pada siklus I ternyata perolehan nilai tes formatif mengalami kenaikan. Rata-rata kelas mencapai 68\%. Nilai tertinggi yang diperoleh anak mencapai 100 sedangkan nilai terendah mencapai 40. Dengan demikian masih perlu diadakan perbaikan pembelajaran pada siklus II agar hasil belajar siswa mencapai nilai maksimal.

Kekurangan yang terjadi pada siklus I diantaranya karena guru kurang dalam memanfaatkan alat peraga dan kurang memberikan latihan. Oleh karena itu, dalam rangka meningkatkan pemahaman siswa terhadap materi mengurutkan bilangan, guru memberikan konsep tentang mengurutkan bilangan secara mendalam kepada siswa. Pada siklus II, nilai tertinggi mencapai 100 sedangkan nilai terendah mencapai 50. Hasil tes formatif yang diperoleh siswa meningkat dengan rata-rata $85 \%$ tuntas. Perolehan nilai sebagian besar siswa sudah mencapau 60 ke atas. Maka perbaikan pembelajaran dapat dinyatakan berhasil melalui siklus II.

\section{Kesimpulan dan Saran}

\subsection{Kesimpulan}

Dari hasil penelitian yang telah dilaksanakan dapat ditarik kesimpulan sebagai berikut:

1) Penggunaan alat peraga dalam kegiatan pembelajaran Matematika sangat berpengaruh dalam meningkatkan hasil belajar siswa.

2) Penggunaan alat peraga mempermudah siswa dalam memahami konsep awal serta menambah keterampilan dan kemampuan siswa dalam belajar Matematika.

3) Penggunaan alat peraga akan membuat siswa lebih aktif dalam kegiatan pembelajaran Matematika, serta meningkatkan kemampuan siswa dalam mengurutkan bilangan. 
4) Pemberian latihan-latihan mampu meningkatkan ketuntasan siswa dalam pembelajaran Matematika

5) Penggunaan metode yang bervariasi dengan melibatkan siswa dapat meningkatkan pemahaman siswa terhadap pelajaran Matematika tentang mengurutkan bilangan.

\subsection{Saran}

Berdasarkan hasil penelitian dan simpulan di atas, peneliti dapat memberikan saran sebagai berikut:

1) Dalam setiap kegiatan pembelajaran para guru diharapkan untuk menggunakan media atau alat peraga untuk mempermudah siswa dalam memahami materi pembelajaran.

2) Dalam setiap kegiatan pembelajaran sebaiknya guru memilih metode pembelajaran yang tepat sehingga dapat membangkitkan kreatifitas siswa dalam belajar.

3) Pemberian bimbingan tepat bagi siswa yang mengalami kesulitan belajar karena sangat berpengaruh terhadap perkembangan dan prestasi belajar siswa selanjutnya.

4) Guru harus aktif dan kreatif agar dapat mengembangkan kualitas profesinya.

\section{Daftar Pustaka}

Karso, dkk. 2003. Pendidikan Matematika I. Jakarta: Univeristas Terbuka

Taufik, Agus, Hera L. Mikarsa, Puji L. Prianto. 2011. Pendidikan Anaka di SD. Jakarta: Universitas Terbuka

Wardani, Igak, dkk. 2011. Teknik Menulis Karya Ilmiah. Jakarta: Universitas Terbuka

Wardani, Igak, Kuswaya Wihardit. 2010. Penelitian Tindakan Kelas. Jakarta: Universitas Terbuka

Winataputra, udin. 2005. Strategi Belajar Mengajar. Jakarta: Universitas Terbuka 